\title{
Audit Sistem Informasi Perpustakaan Pada SMK Tunas Harapan Dengan Menggunakan Framework Cobit 4.1
}

\author{
Ria Fitriana ${ }^{1}$, Jamal Maulana Hudin², Erika Mutiara ${ }^{3}$ \\ 1,2 STMIK Nusa Mandiri \\ ria.fitriana.98@gmail.com \\ 3Universitas Bina Sarana Informatika \\ erika.emb@bsi.ac.id
}

\begin{abstract}
Abstraksi
Perkembangan Teknologi Informasi (TI) dapat meningkatkan keunggulan bersaing suatu organisasi, sehingga banyak organisasi bergantung pada TI, tidak terkecuali dengan SMK Tunas Harapan. Dalam menjalankan aktivitas layanannya, SMK Tunas Harapan didukung oleh Sistem Informasi Perpustakaan. Konsep Information of Technology (IT) governance adalah cara mengelola penggunaan teknologi informasi di sebuah organisasi. IT Governance menggabungkan good practices dari perencanaan dan pengorganisasian, pembangunan dan pengimplementasian, penyaluran dan pelayanan, serta memonitor kinerja sistem informasi untuk memastikan informasi dan teknologi yang dapat mendukung tujuan dan misi organisasi. Salah satu cara mengetahui hal tersebut adalah dengan melakukan proses audit dan analisi terhadap sistem tersebut. COBIT (Control Obejctive for Information and Related Technology) adalah standar control SI yang sifatnya umum serta dapat diterima dan diterapkan oleh organisasi. Penelitian ini bertujuan untuk melakukan analisis sistem informasi perpustakaan SMK Tunas Harapan dengan cara melakukan analisis internal controlnya menggunakan COBIT framework. IT Maturity Model merupakan model yang digunakan untuk mengukur tingkat kematangan pengelolaan teknologi informasi dalam suatu organisas, yang meliputi : tingkat 0 (non-existent), tingkat 1 (initial), tingkat 2 (repeateable), tingkat 3 (defined), tingkat 4 (managed) dan tingkat 5 (optimised). Semakin tinggi maturity level akan semakin baik proses pengelolaan teknologi informasi. Dalam penelitian ini, menggunakan domain delivery and support (DS) dipilih untuk melakukan analisis pada setiap level proses IT COBIT. Dari hasil penelitihan ini diperoleh data tingkat kematangan Sistem Informasi Perpustakaan pada level rata-rata 2,67 (repeatable but intuitive) dari domain DS1, DS4, DS5, DS7, DS8, DS10, DS11 dan DS12.
\end{abstract}

Kata Kunci: Sistem Informasi Perpustakaan, Internal Control, Cobit Framework

\begin{abstract}
The development of Information Technology (IT) can increase the competitive advantage of an organization, so that many organizations rely on IT, including SMK Tunas Harapan. In carrying out its service activities, SMK Tunas Harapan is supported by a Library Information System. The concept of Information of Technology (IT) governance is a way of managing the use of information technology in an organization. IT Governance combines good practices from planning and organizing, developing and implementing, distributing and providing services, as well as monitoring information system performance to ensure information and technology can support organizational goals and missions. One way to know this is by conducting an audit and analyzing the system. COBIT (Control Objective for Information and Related Technology) is an IS control standard that is general in nature and can be accepted and implemented by organizations. This study aims to analyze the information system of the Tunas Harapan SMK library by analyzing its internal control using the COBIT framework. The IT Maturity Model is a model used to measure the maturity level of information technology management in an organization, which includes: level 0 (non-existent), level 1 (initial), level 2 (repeateable), level 3 (defined), level 4 (managed) and level 5 (optimized). The higher the maturity level, the better the information technology management process. In this study, using the domain delivery and support (DS) was chosen to perform analysis at each level of the IT COBIT process. From the results of this research, it is obtained that the maturity level of the Library Information System is at an average level of 2.67 (repeatable but intuitive) from the DS1, DS4, DS5, DS7, DS8, DS10, DS11 and DS12 domains.
\end{abstract}

Keywords: Library Information System, Internal Control, Cobit Framework 


\section{PENDAHULUAN}

Perkembangan teknologi saat ini sangat cepat, khususnya pada suatu instansi atau organisasi yang sangat membutuhkan suatu informasi untuk pengambilan keputusan. Informasi dapat diibaratkan sebagai darah yang mengalir di dalam tubuh manusia, seperti halnya informasi didalam sebuah lembaga pendidikan yang sangat penting untuk mendukung kelangsungan perkembangannya, sehingga informasi sangat dibutuhkan bagi sebuah lembaga pendidikan dalam mengolah data. Pengolahan data memerlukan suatu sistem agar informasi yang diperoleh berkualitas dan bernilai bagi instansi yang bersangkutan.

$\mathrm{Di}$ era globalisasi yang sudah berlangsung pada saat ini merupakan

kenyataan yang tidak dapat dihindari termasuk kelebihan dan kekurangannya. Hal ini berkat dari perkembangan dan kemajuan teknologi informasi (TI). Perkembangan teknologi informasi yang sangat cepat dewasa ini sangat mempengaruhi berbagai segi kehidupan dan profesi.

Hal ini menyebabkan perubahan sistem pada instansi atau perusahaan, yang berdampak juga pada perubahan cara kerja mereka. Teknologi informasi banyak diterapkan untuk pengelolaan pekerjaan karena daya efektivitas dan efisiensinya yang sudah terbukti mampu mempercepat kinerja, yang pada akhirnya akan meningkatkan keuntungan yang masuk, baik secara finansial maupun jaringan.

Teknologi informasi saat ini telah menyebar hampir di semua aspek kehidupan dan profesi, tidak terkecuali perpustakaan. Perpustakaan sebagai institusi yang berkecimpung di bidang pengelolaan sumber informasi sudah seharusnya terjamah penerapan teknologi informasi. Dengan adanya teknologi informasi diharapkan dapat membantu untuk mempercepat penggunaan dalam memperoleh kebutuhan informasi dan membuat sistem agar layanan perpustakaan tersistematis.

Penerapan teknologi informasi di perpustakaan dapat difungsikan dalam berbagai bentuk, salah satunya adalah sebagai Sistem Informasi Perpustakaan.
Bidang pekerjaan yang dapat diintegrasikan dengan sistem informasi perpustakaan adalah pengadaan, inventarisasi, katalogisasi, sirkulasi bahan pustaka, pengelolaan anggota, statistik, dan sebagainya. Fungsi ini diistilahkan sebagai otomasi perpustakaan. Berdasarkan hasil observasi awal yang penulis lakukan, ternyata sistem informasi perpustakaan Smk Tunas Harapan terkadang tidak akurat dan lambat dalam memperbaharui pangkalan datanya.

\section{DEFINISI AUDIT}

Pengauditan (auditing) didefinisikan sebagai suatu proses yang sistematis untuk memperoleh dan mengevaluasi (secara obyektif) bukti yang berhubungan dengan asersi tentang tindakan-tindakan dan kejadian ekonomi, dalam rangka menentukan tingkat kepatuhan antara asersi dengan kriteria yang telah ditetapkan, serta mengkomunikasikan hasilnya kepada pihakpihak yang berkepentingan.

\section{KONSEP DASAR INFORMASI}

Sistem informasi adalah suatu sistem di dalam suatu organisasi yang mempertemukan kebutuhan pengolahan transaksi harian, mendukung informasi, bersifat manajerial dan kegiatan strategi dari suatu organisasi dan menyediakan pihak luar tertentu dengan laporan-laporan yang diperlukan. [1]

\section{SISTEM DAN INFORMASI}

Sistem adalah kumpulan orang yang saling bekerja sama dengan ketentuanketentuan aturan yang sistematis dan terstruktur untuk membentuk satu kesatuan yang melaksanakan suatu fungsi untuk mencapai tujuan. Sistem memiliki beberapa karakteristik atau sifat yang terdiri dari komponen sistem, batasan sistem, lingkungan luar sistem, penghubung sistem, masukan sistem, keluaran sistem, pengolahan sistem dan sasaran sistem.

Sedangkan informasi adalah data yang diolah menjadi lebih berguna dan berarti bagi penerimanya, serta untuk mengurangi 
ketidakpastian dalam proses pengambilan keputusan mengenai suatu keadaan. Sistem informasi merupakan suatu kombinasi teratur dari orang-orang, hardware, software, jaringan komunikasi dan sumber daya data yang mengumpulkan, mengubah, dan menyebarkan informasi dalam sebuah organisasi.

\section{AUDIT SISTEM INFORMASI}

Audit Sistem Informasi adalah proses pengumpulan dan penilaian bukti - bukti untuk menentukan apakah "sistem computer" dapat mengamankan aset, memelihara integritas data, dapat mendorong pencapaian tujuan organisasi secara efektif dan menggunakan sumber daya secara efisien). [2]

Audit Teknologi informasi pada hakekatnya merupakan salah satu dari bentuk audit operasional, tetapi kini audit teknologi informasi sudah dikenal sebagai satu satuan jenis audit tersendiri yang tujuan utamanya lebih untuk meningkatkan tata kelola IT. Sebagai suatu audit operasional terhadap manajemen sumber daya informasi, yaitu efektivitas, efisiensi, dan ekonomis tidaknya unit fungsional sistem informasi pada suatu organisasi.

Dengan diperkenalkan COBIT, kini tujuan audit bukan hanya terbatas pada konsep klasik saja, melainkan kini menjadi: efektivitas, efisiensi, kerahasiaan, keterpaduan, ketersediaan, kepatuhan pada kebijakan/aturan dan keandalan sistem informasi. Dalam pelaksanaannya, jenis audit ini berkembang dalam beberapa variannya:

1. Pemeriksaaan operasional (operational audit) terhadap pengelolaan sistem informasinya, atau lebih tepatnya/tegasnya terhadap tata-kelola teknologi informasi (IT governance),

2. General information review, audit terhadap sistem informasi secara umum pada suatu organisasi tertentu

3. Audit terhadap aplikasi tertentu yang sedang dikembangkan (quality assurance pada tahap sistem development). [3]

\section{PERPUSTAKAAN}

a. Unit Pelaksana Teknis Perpustakaan
Perpustakaan sekolah merupakan perpustakaan yang bertugas sebagai suatu unit pelaksana teknis, mengemban tugas mendukung tujuan lembaga induknya,yaitu memberikan layanan kepada sivitas akademika dan masyarakat pemakai di sekitarnya, yang relevan dengan program SMK Tunas Harapan, yaitu pendidikan dan pengajaran, penelitian dan pengabdian kepada masyarakat.

Secara umum tujuan perpustakaan sekolah adalah: (1) memenuhi keperluan informasi masyarakat sekolah, lazimnya staf pengajar dan murid. Sering pula mencakup pula tenaga administrasi sekolah, (2) menyediakan bahan pustaka rujukan (referens) pada semua tingkat akademis, artinya mulai dari murid dan staf pengajar, (3) menyediakan ruangan belajar untuk pemakai perpustakaan, (4) menyediakan jasa peminjaman yang tepat guna bagi berbagai jenis pemakaian, dan (5) menyediakan jasa informasi aktif yang tidak saja terbatas pada lingkungan sekolah tetapi juga lembaga industri local.

\section{b. Pengukuran Sistem Informasi}

Suatu software (sistem informasi) dikembangkan melalui pengamatan dari sebuah proses kerja, untuk menilai suatu software tentu ada banyak kriteria yang harus diperhatikan. memberikan beberapa kriteria untuk menilai suatu system informasi adalah sebagai berikut:

1. Kegunaan Fasilitas dan aplikasi yang tersedia sesuai dengan kebutuhan serta menghasilkan informasi (output) dengan cepat dan relevan untuk proses pengambilan keputusan.

2. Ekonomis Biaya yang dikeluarkan untuk mengapilaksikan software sebanding dengan hasil yang didapatkan.

3. Keandalan Software yang digunakan mampu menangani operasi pekerjaan porsi besar dengan frekuensi yang tinggi dan terus-menerus.

4. Kapasitas Software yang digunakan mampu menyimpan data dengan kapasitas yang besar dan kemampuan temu kembali yang cepat.

5. Sederhana menu dan navigasi yang disediakan dapat dijalankan dengan mudah dan interaktif dengan pengguna.

6. Fleksibel Software yang digunakan dapat diaplikasikan dan dioperasikan dalam beberapa jenis sistem operasi serta memiliki potensi untuk selalu dikembangkan. 


\section{DEFINISI COBIT}

COBIT (Control Objective for Information and Related Technology) adalah suatu metodologi yang memberikan kerangka dasar dalam menciptakan sebuah Teknologi Informasi yang sesuai dengan kebutuhan organisasi.

Sekumpulan dokumentasi best practices untuk IT governance yang dapat membantu auditor, manajemen dan pengguna untuk menjembatani gap antara resiko bisnis, kebutuhan kontrol dan permasalahan teknis.

COBIT adalah suatu framework untuk membangun suatu IT Governance. Dengan mengacu pada framework COBIT, suatu organisasi diharapkan mampu menerapkan IT governance dalam pencapaian tujuannya IT governance mengintegrasikan cara optimal dari proses perencanaan dan pengorganisasian, pengimplementasian, dukungan serta proses pemantauan kinerja Teknologi Informasi.

COBIT memiliki fungsi antara lain:

a. Meningkatkan pendekatan/program audit.

b. b.Mendukung audit kerja dengan arahan audit secara rinci.

c. c.Memberikan petunjuk untuk IT governance.

d. d.Sebagai penilaian benchmark untuk kendali Sistem Informasi/Teknologi Informasi.

e. e.Meningkatkan kontrol Sistem Informasi/Teknologi Informasi.

f. Sebagai standarisasi pendekatan/program audit. [4]

\section{COBIT 4.1}

COBIT (Control Objectives for Information and Related Technology) merupakan sekumpulan dokumentasi dan panduan yang mengarahkan pada IT governance yang bisamembantu auditor, manajemen, dan pengguna (user) untuk menjembatani pemisah antara resiko bisnis, kebutuhan kontrol, dan permasalahanpermasalahan teknis. COBIT dikembangkan oleh IT governance Institute (ITGI) yang merupakan bagian dari Information Systems Audit and Control Association (ISACA).

COBIT mengelompokkan semua aktivitas bisnis yang terjadi dalam organisasi menjadi
34 proses yang terbagi ke dalam empat buah domain proses, meliputi :

a. Plan and Organise (10 proses), meliputi strategi dan taktik yang berkaitan dengan identifikasi pemanfaatan IT yang dapat memberikan kontribusi dalam pencapaian tujuan bisnis.

b. Acquire and Implement (7 proses), merupakan domain proses yang merealisasikan strategi IT, serta solusisolusi IT yang diperlukan untuk diterapkan pada proses bisnis organisasi. Pada domain ini pula dilakukan pengelolaan perubahan terhadap system eksisting untuk menjamin proses yang berkesinambungan.

c. Deliver and Support (13 proses), yaitu domain proses yang berhubungan dengan pelayanan yang diberikan, mulai dari operasi tradisional terhadap keamanan dan aspek kesinambungan hingga pelatihan.

d. Monitor and Evaluate (4 proses), merupakan domain yang memberikan pandangan bagi pihak manajemen berkaitan dengan kualitas dan kepatuhan dari proses yang berlangsung dengan kendali-kendali yang diisyaratkan.

DS (Delivery and Support), merupakan domain proses yang berhubungan dengan pelayanan yang diberikan, mulai dari operasi tradisional terhadap keamanan dan aspek kesinambungan hingga pelatihan. Sebelumnya, terlebih dahulu perlu ditetapkan proses-proses pendukung yang berpengaruh terhadap pelayan. Domain ini melibatkan pemrosesan data yang sebenarnya dengan menggunakan sistem aplikasi, yang diklasifikasikan ke dalam kendali aplikasi.Kendali yang ditetapkan pada domain proses DS harus dapat menjelaskan pertanyaan -pertanyaan seperti :

a. Apakah layanan IT telah sesuai dengan prioritas bisnis ?

b. Apakah biaya IT telah optimal ?

c. Apakah organisasi mampu menggunakan perangkat IT secara produktif dan aman?

d. Adakah mekanisme yang cukup untuk menjamin keamanan informasi (confidentiality, integrity and availability) ?

Delivery and Support (13 proses), yaitu domain proses yang berhubungan dengan pelayanan yang diberikan, mulai dari operasi tradisional terhadap keamanan dan 
aspek kesinambungan hingga pelatihan yang meliputi :
a. DS1 Menentukan dan mengatur tingkat layanan
b. DS2 Mengatur layanan dengan pihak ketiga
c. DS3 Mengatur kinerja dan kapasitas
d. DS4 Memastikan keberlanjutan layanan
e. DS5 Memastikan keamanan sistem
f. DS6 Mengidentifikasi dan Mengalokasikan Biaya
g. DS7 Mendidik dan melatih pengguna
h. DS8 Mengelola bantuan layanan dan insiden
i. DS9 Mengelola Konfigurasi
j. DS10 Mengelola masalah
k. DS11 Mengelola data
I. DS12 Mengelola fasilitas
m. DS13 Mengelola operasi

\section{MATURITY MODEL}

IT Maturity Model merupakan model yang digunakan untuk mengukur tingkat kematangan pengelolaan teknologi informasi dalam suatu organisasi. IT Maturity Model terdiri dari lima tingkat kematangan pengelolaan IT, meliputi : tingkat 0 (non-existent), tingkat 1 (initial), tingkat 2 (repeateable), tingkat 3 (defined), tingkat 4 (managed) dan tingkat 5 (optimised).

Semakin tinggi maturity level akan semakin baik proses pengelolaan teknologi informasi, yang secara tidak langsung bermakna semakin reliable dukungan teknologi informasi dalam proses pencapaian tujuan organisasi. Berikut ini adalah tabel kriteria untuk menilai hasil evaluasi dari Maturity Model :

Table 1 Tingkat Maturity Model

\begin{tabular}{ccl}
\hline No & Nilai Kematengan & Tingkat Kematengan \\
\hline 1 & 0,00 & 0 Non-existent \\
\hline 2 & 1,00 & 1 InitialAd Hoc \\
\hline 3 & 2,00 & $\begin{array}{l}\text { 2 Repeatable but } \\
\text { intuitive }\end{array}$ \\
\hline 4 & 3,00 & $\begin{array}{l}3 \text { Defined process } \\
\text { 4 Managed and } \\
\text { Measurable }\end{array}$ \\
\hline 5 & 4,00 & 5 Optimised \\
\hline 6 & 5,00 &
\end{tabular}

Sumber : COBIT ISACA

\section{PEMBAHASAN TINGKAT KEMATENGAN}

Berikut hasil Implem entasi Sistem Informasi Perpustakaan SMK Tunas Harapan mengenai analisis hasil pengukuran tingkat kematangan berdasarkan setiap proses yang diukur. Adapun Hasil Perhitungan DS1 Menetapkan dan Mengatur Tingkat Layanan, untuk Maturity Level 0-5 dari Satu Responden yaitu :

Table 2 Hasil Perhitungan DS 1 level 0-5 dari satu Responden

\begin{tabular}{|c|c|c|c|c|c|c|c|}
\hline \multicolumn{4}{|c|}{$\begin{array}{l}\text { Computation of the Maturity Level } \\
\text { Compliences Value }\end{array}$} & \multicolumn{2}{|c|}{$\begin{array}{l}\text { Computation of the } \\
\text { normalized } \\
\text { Complience } \\
\text { Vektor }\end{array}$} & \multicolumn{2}{|c|}{$\begin{array}{l}\text { Computation of the } \\
\text { Summary } \\
\text { Maturity Leve }\end{array}$} \\
\hline $\begin{array}{l}\text { Maturi } \\
\text { ty } \\
\text { Level } \\
\text { (A) }\end{array}$ & $\begin{array}{c}\text { Sum of } \\
\text { statement } \\
\text { s } \\
\text { complian } \\
\text { œ values } \\
\text { (B) }\end{array}$ & $\begin{array}{c}\text { Numbe } \\
\text { r of } \\
\text { maturity } \\
\text { level } \\
\text { stateme } \\
\text { nts (C) }\end{array}$ & $\begin{array}{l}\text { Maturity } \\
\text { level } \\
\text { complienc } \\
\text { e value } \\
D=(B / C)\end{array}$ & $\begin{array}{c}\text { Not } \\
\text { nommalized } \\
\text { compliences } \\
\text { values } \\
\mathrm{E}=(\mathrm{B} / \mathrm{C})\end{array}$ & $\begin{array}{c}\text { Normali } \\
\text { zed } \\
\text { complien } \\
\text { ces } \\
\text { values } \\
\mathrm{F}=[\mathrm{E} / \mathrm{S} u \\
\mathrm{m}(\mathrm{E})]\end{array}$ & $\begin{array}{c}\text { Normalized } \\
\text { complienœes } \\
\text { values } \\
G=[E / S u m[E)]\end{array}$ & $\begin{array}{l}\text { Contrib } \\
\text { ution } \\
H=(A \\
\left.{ }^{2} G\right)\end{array}$ \\
\hline 0 & 0,00 & 2 & 0,00 & $\begin{array}{c}0,0 \\
0\end{array}$ & 0,000 & 0,000 & 0,00 \\
\hline 1 & 1,32 & 4 & 0,33 & $\begin{array}{c}0,3 \\
3\end{array}$ & 0,228 & 0,228 & 0,23 \\
\hline 2 & 0,00 & 5 & 0,00 & $\begin{array}{c}0,0 \\
0\end{array}$ & 0,000 & 0,000 & 0,00 \\
\hline 3 & 1,32 & 6 & 0,22 & $\begin{array}{c}0,2 \\
2\end{array}$ & 0,152 & 0,152 & 0,46 \\
\hline 4 & 3,97 & 7 & 0,57 & $\begin{array}{c}0,5 \\
7\end{array}$ & 0,392 & 0,392 & 1,57 \\
\hline \multirow[t]{2}{*}{5} & 1,65 & 5 & 0,33 & $\begin{array}{c}0,3 \\
3\end{array}$ & 0,228 & 0,228 & 1,14 \\
\hline & & & Total & $\begin{array}{c}1,4 \\
5\end{array}$ & 1,000 & $\begin{array}{l}\text { Total Maturity } \\
\text { Level }\end{array}$ & 3,39 \\
\hline
\end{tabular}

Kendali proses DS1 pembahasan tentang penetapan dan pengaturan tingkat layanan.Penetapan dan pengaturan tingkat layanan sangat dibutuhkan, sehingga setiap individu memiliki tanggung jawab sesuai dengan peranannya masing-masing. Tabel 2 diatas menunjukkan nilai hasil yang diperoleh adalah 3,39 (Defined process).

Hasil tersebut menunjukkan bahwa SMK Tunas Harapan telah memiliki definisi yang 
jelas mengenai tanggung jawab meskipun dengan otoritas yang bebas. Setiap kegagalan layanan Didefinisikan namun solusinya hanya bersifat informal. Namun demikian belum ada pengukuran kepuasan pelanggan secara rutin. Adapun Hasil Perhitungan DS4 Memastikan Ketersediaan Layanan, untuk Maturity Level 0-5 dari Satu Responden Yaitu :

\section{Table 3 Hasil Perhitungan DS4 Level 0-5 dari Satu Responden}

\begin{tabular}{|c|c|c|c|c|c|c|c|}
\hline \multicolumn{4}{|c|}{$\begin{array}{l}\text { Computation of the Maturity Level } \\
\text { Compliences Value }\end{array}$} & \multicolumn{2}{|c|}{$\begin{array}{l}\text { Computation of the } \\
\text { norm sized } \\
\text { Complience Vetior }\end{array}$} & \multicolumn{2}{|c|}{$\begin{array}{l}\text { Compotation of the Summary } \\
\text { Maturity Level }\end{array}$} \\
\hline $\begin{array}{l}\text { Mat } \\
\text { uffy } \\
\text { Level } \\
\text { [a] }\end{array}$ & $\begin{array}{c}\text { Sum of } \\
\text { statements } \\
\text { complanoe } \\
\text { values }(B)\end{array}$ & $\begin{array}{c}\text { Number } \\
\text { of } \\
\text { maturity } \\
\text { level } \\
\text { statemen } \\
\text { is (c) }\end{array}$ & $\begin{array}{l}\text { Maturitz level } \\
\text { complience } \\
\text { value } D=\{(B, C)\end{array}$ & $\begin{array}{l}\text { Natncemalized } \\
\text { complierces } \\
\text { valives } E[B,[/ C)\end{array}$ & $\begin{array}{c}\text { Normatiz } \\
\text { ed } \\
\text { complierc } \\
\text { esvalues } \\
\mathrm{F}=[\mathrm{E} / \mathrm{S} \text { Sum(E) } \\
\text { I] }\end{array}$ & $\begin{array}{c}\text { Normatized } \\
\text { compliences } \\
\text { values } \\
\text { G=[ESumi:El] }\end{array}$ & $\begin{array}{c}\text { Consfitution } \\
H=(\hat{A} \cdot G)\end{array}$ \\
\hline 0 & $\begin{array}{l}0,3 \\
3 \\
\end{array}$ & & 0,17 & 0,17 & 0,064 & 0,064 & 0,00 \\
\hline 1 & $\begin{array}{l}1,6 \\
5 \\
\end{array}$ & & 0,33 & 0,33 & 0,127 & 0,127 & 0,13 \\
\hline 2 & $\begin{array}{l}3,6 \\
5 \\
\end{array}$ & & 0,61 & 0,61 & 0,235 & 0,235 & 0,47 \\
\hline 3 & $\begin{array}{l}3,6 \\
4 \\
\end{array}$ & & 0,46 & 0,46 & 0,176 & 0,176 & 0,53 \\
\hline 4 & $\begin{array}{l}4,9 \\
7 \\
\end{array}$ & & 0,55 & 0,55 & 0,213 & 0,213 & 0,85 \\
\hline 5 & 4,3 & & $\frac{0,48}{\text { Total }}$ & $\frac{0,48}{2,59}$ & $\frac{0,185}{1,000}$ & $\begin{array}{l}0,185 \\
\begin{array}{c}\text { Total Maturiay } \\
\text { Level }\end{array} \\
\end{array}$ & 0,92 \\
\hline
\end{tabular}

Kendali proses DS4 pembahasan tentang kepastian ketersediaan layanan. Perpustakaan SMK Tunas Harapan sebagai organisasi yang bergerak dalam bidang layanan, harus dapat memastikan layanan yang tersedia berjalan dengan baik sehingga kebutuhan pengguna terpenuhi.

Tabel 3 diatas menunjukkan nilai hasil yang dicapai adalah 2,90 (Repeatable but Intuitive). Hal tersebut menggambarkan bahwa praktek kesinambungan layanan merupakan hal yang wajib, namun kesuksesannya bergantung pada individu. Adapun Hasil Perhitungan DS5 Memastikan Keamanan Sistem, untuk Maturity Level 0-5 dari Satu Responden yaitu :

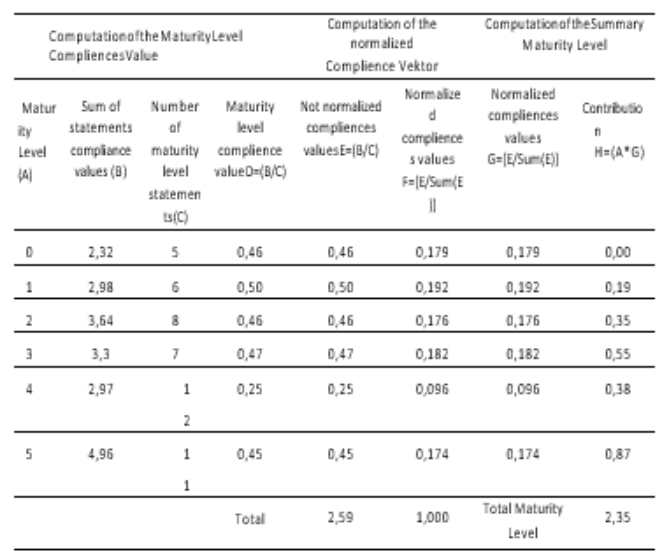

Kendali proses DS5 adalah pembahasan tentang memastikan keamanan sistem. Sistem Informasi Perpustakaan sebagai teknologi baru, dalam penerapannya tentu membutuhkan pengamanan. Oleh karena itu keamanan sistem harus dipastikan terlebih dahulu.

Tabel 4 diatas menunjukkan nilai hasil yang dicapai adalah 2,35 (Repeatable but intuitive). Hasil tersebut menggambarkan bahwa tanggung jawab dan akuntabilitas keamanan $\mathrm{TI}$ ditugaskan kepada pengelola keamanan $\mathrm{TI}$ dengan otoritas terbatas. Pelaporan tentang keamanan TI lengkap namun kurang sesuai. Keamanan TI hanya dilihat sebagai tanggung jawab domain dan bisnis $\mathrm{TI}$ dan tidak melihat keamanan $\mathrm{TI}$ sebagai bagiannya. Mengingat pentingnya keamanan TI maka tanggung jawab atas hal tersebut harus ditetapkan. Resiko dan analisis dampak keamanan $\mathrm{TI}$ secara konsisten dilakukan. Adapun Hasil Perhitungan DS7 Mendidik dan Melatih Pengguna, untuk Maturity Level 0-5 dari Satu Responden yaitu : 


\begin{tabular}{|c|c|c|c|c|c|c|c|}
\hline \multicolumn{4}{|c|}{$\begin{array}{l}\text { Computationofthe Maturitylevel } \\
\text { Compliencesvalue }\end{array}$} & \multicolumn{2}{|c|}{$\begin{array}{l}\text { Computation of the } \\
\text { normaliced } \\
\text { Complience Vektor }\end{array}$} & \multicolumn{2}{|c|}{$\begin{array}{l}\text { Computation af the } \\
\text { Summary } \\
\text { Maturity Level }\end{array}$} \\
\hline $\begin{array}{l}\text { Matur } \\
\text { ialy } \\
\text { Level } \\
\text { ial }\end{array}$ & $\begin{array}{l}\text { Sum of } \\
\text { statemen } \\
\text { is } \\
\text { complianc } \\
\text { e values } \\
\text { (घ) }\end{array}$ & $\begin{array}{l}\text { Number } \\
\text { of } \\
\text { maturity } \\
\text { level } \\
\text { statemen } \\
\text { ts(c) }\end{array}$ & $\begin{array}{l}\text { Maturitylevel } \\
\text { complience } \\
\text { value } D=(B / C)\end{array}$ & 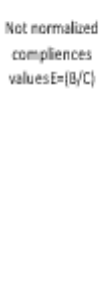 & 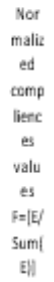 & $\begin{array}{l}\text { Normalized } \\
\text { compliences } \\
\text { values } \\
G=[E / S u m \mid E]\end{array}$ & $\begin{array}{l}\text { Centritu } \\
\text { ticn } \\
H=(\hat{\alpha} \cdot \\
G)\end{array}$ \\
\hline 0 & 0,33 & 2 & 0,17 & 0,17 & 0,071 & 0,071 & 0,00 \\
\hline 1 & 1,32 & 4 & 0,33 & 0,33 & 0,143 & 0,143 & 0,14 \\
\hline 2 & 3,31 & 6 & 0,55 & 0,55 & 0,239 & 0,239 & 0,48 \\
\hline 3 & 1,98 & 6 & 0,33 & 0,33 & 0,143 & 0,143 & 0,43 \\
\hline 4 & 3,64 & 7 & 0,52 & 0,52 & 0,225 & 0,225 & 0,90 \\
\hline \multirow[t]{2}{*}{5} & 3,3 & 8 & 0,41 & 0,41 & 0,179 & 0,179 & 0,89 \\
\hline & & & Total & 2,31 & 1,000 & $\begin{array}{c}\text { Total Maturity } \\
\text { Level }\end{array}$ & 2,84 \\
\hline
\end{tabular}

Kendali proses DS7 adalah pembahasan tentang mendidik dan melatih pengguna. Pada proses ini dibahas mengenai bagaimana mencapai tujuan penerapan teknologi Sistem Informasi dengan cara membangun sumber daya manusia sebagai pengguna teknologi tersebut. Tabel 5 diatas menunjukkan nilai hasil yang diperoleh adalah 2,84 (Repeatable but Intuitive). Hal tersebut menggambarkan bahwa kebutuhan akan adanya pelatihan mulai diidentifikasi dalam rencana kinerja individu karyawan akan tetapi belum memiliki proses pelatihan dan pendidikan yang standar dan didokumentasikan. Selain itu tidak ada kontrol terhadap kepatuhan pelaksanaan dengan terus menerus meninjau dan memperbaharui program dan proses pendidikan dan pelatihan. Adapun Hasil Perhitungan DS8 Mengelola Bantuan Layanan dan Insiden, untuk Maturity Level 0-5 dari Satu Responden Yaitu :

Table 6 Hasil Perhitungan DS 8 Level 0-5 dari Satu Responden

\begin{tabular}{|c|c|c|c|c|c|c|c|}
\hline \multicolumn{4}{|c|}{$\begin{array}{l}\text { Computation ofthe Maturiylevel } \\
\text { Compliencesvalue }\end{array}$} & \multicolumn{2}{|c|}{$\begin{array}{l}\text { Computation of the } \\
\text { normalized } \\
\text { Complience Vektor }\end{array}$} & \multicolumn{2}{|c|}{$\begin{array}{l}\text { Computationofthe Summary } \\
\text { Maturity Level }\end{array}$} \\
\hline $\begin{array}{l}\text { Maturi } \\
\text { ty Lerel } \\
\text { [a| }\end{array}$ & 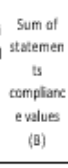 & $\begin{array}{l}\text { Number } \\
\text { of } \\
\text { maturity } \\
\text { level } \\
\text { sttesemen } \\
\text { sis(c) }\end{array}$ & $\begin{array}{l}\text { Maturitylevel } \\
\text { complience } \\
\text { value } D=(B / C)\end{array}$ & $\begin{array}{l}\text { Not rermalived } \\
\text { compliences } \\
\text { values } E=[\mathrm{B} / \mathrm{C}]\end{array}$ & $\begin{array}{c}\text { Noma } \\
\text { lieed } \\
\text { compi } \\
\text { ences } \\
\text { values } \\
\mathrm{F}=[\mathrm{E} / \mathrm{S} \text { Sum } \\
(\mathrm{E})]\end{array}$ & 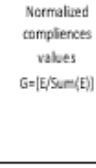 & $\begin{array}{l}\text { Contribe } \\
\text { ticn } \\
H=\left(\lambda^{*} .\right. \\
G)\end{array}$ \\
\hline 0 & 1,33 & 3 & 0,44 & 0,44 & 0,158 & $0,15 \mathrm{~B}$ & 0,00 \\
\hline 1 & 1,99 & 4 & 0,50 & 0,50 & 0,177 & 0,177 & 0,18 \\
\hline 2 & 1,99 & 4 & 0,50 & 0,50 & 0,177 & 0,177 & 0,35 \\
\hline 3 & 2,98 & 7 & 0,43 & 0,43 & 0,152 & 0,152 & 0,45 \\
\hline 4 & 3,31 & 7 & 0,47 & 0,47 & 0,168 & $0,16 \mathrm{~B}$ & 0,67 \\
\hline \multirow[t]{2}{*}{5} & 3,31 & 7 & 0,47 & 0,47 & 0,168 & $0,16 \mathrm{~B}$ & 0,84 \\
\hline & & & Total & 2,81 & 1,000 & $\begin{array}{l}\text { Total Mutunity } \\
\text { Level }\end{array}$ & 2,50 \\
\hline
\end{tabular}

Kendali proses DS8 pembahasan tentang pengelolaan bantuan layanan dan insiden. Dalam hal ini dibahas tentang bagaimana pengelolaan bantuan layanan dan insiden terkait penerapan Sistem Informasi sebagai teknologi informasi.

Tabel 6 diatas menunjukkan nilai hasil yang diperoleh adalah 2,50 (Repeatable but intuitive). Hasil tersebut menggambarkan bahwa dalam memenuhi permintaan pengguna dan pengelolaan insiden belum menggunakan suatu standar system yang didukung oleh kualitas alat dan personilnya. Adapun Hasil Perhitungan DS10 Mengelola Masalah, untuk Maturity Level 0-5 dari Satu Responden yaitu :

Table 7 Hasil Perhitungan DS10 Level 0-5 dari Satu Responden

\begin{tabular}{|c|c|c|c|c|c|c|c|}
\hline \multicolumn{4}{|c|}{$\begin{array}{l}\text { ComputationoftheMaturitylevel } \\
\text { CompliencesValue }\end{array}$} & \multicolumn{2}{|c|}{$\begin{array}{l}\text { Computation of the } \\
\text { normalized } \\
\text { Complience Vektor }\end{array}$} & \multicolumn{2}{|c|}{$\begin{array}{l}\text { ComputationoftheSummary } \\
\text { Maturity Level }\end{array}$} \\
\hline $\begin{array}{l}\text { Maturi } \\
\text { ty } \\
\text { Level } \\
\text { (A) }\end{array}$ & $\begin{array}{c}\text { Sum of } \\
\text { statements } \\
\text { compliance } \\
\text { values (B) }\end{array}$ & $\begin{array}{c}\text { Number } \\
\text { of } \\
\text { maturity } \\
\text { level } \\
\text { statement } \\
s(C)\end{array}$ & $\begin{array}{c}\text { Maturitylevel } \\
\text { complience } \\
\text { value } D=(B / C)\end{array}$ & $\begin{array}{c}\text { Not normalized } \\
\text { compliences } \\
\text { valuesE }=(B / C)\end{array}$ & 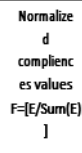 & $\begin{array}{c}\text { Normalized } \\
\text { compliences } \\
\text { values } \\
G=[E / \operatorname{sum}(E)]\end{array}$ & $\begin{array}{l}\text { Contributio } \\
n \\
\mathrm{H}=\left(\mathrm{A}^{ \pm} G\right)\end{array}$ \\
\hline 0 & 0,33 & 2 & 0,17 & 0,17 & 0,062 & 0,062 & 0,00 \\
\hline 1 & 1,32 & 3 & 0,44 & 0,44 & 0,166 & 0,166 & 0,17 \\
\hline 2 & 2,65 & 4 & 0,66 & 0,66 & 0,250 & 0,250 & 0,50 \\
\hline 3 & 2,65 & 6 & 0,44 & 0,44 & 0,166 & 0,166 & 0,50 \\
\hline 4 & 3,64 & 7 & 0,52 & 0,52 & 0,196 & 0,196 & 0,78 \\
\hline \multirow[t]{2}{*}{5} & 2,98 & 7 & 0,43 & 0,43 & 0,160 & 0,160 & 0,80 \\
\hline & & & Total & 2,65 & 1,000 & $\begin{array}{c}\text { Total } \\
\text { Maturity } \\
\text { Level }\end{array}$ & 2,75 \\
\hline
\end{tabular}

Kendali proses DS10 pembahasan tentang pengelolaan masalah. Dalam hal ini di bahas bagaimana mengelola masalah yang muncul saat penerapan Sistem Informasi.

Tabel 7 diatas menunjukkan nilai hasil yang diperoleh adalah 2,75 (Repeatable but intuitive). Hasil tersebut menggambarkan bahwa pada setiap masalah yang muncul saat penerapan Sistem Informasi belum dapat terkelola dengan baik. Hal tersebut dikarenakan tidak adanya personil khusus yang mampu mengindentifikasi masalah dan memberikan solusi. Selain itu, belum dimilikinya suatu alur proses mulai dari pendataan masalah, identifikasi masalah, disposisi penanggung jawab penanganan masalah hingga solusi dari masalah tersebut. Adapun Hasil Perhitungan DS11 Mengelola Data, untuk Maturity Level 0-5 dari Satu Responden Yaitu : 
Table 8 Hasil Perhitungan DS 11 Level 0-5 dari Satu Responden

\begin{tabular}{|c|c|c|c|c|c|c|c|}
\hline \multicolumn{4}{|c|}{$\begin{array}{l}\text { ComputationoftheMaturitylevel } \\
\text { CompliencesValue }\end{array}$} & \multicolumn{2}{|c|}{$\begin{array}{l}\text { Computation of the } \\
\text { normalized } \\
\text { Complience Veltor }\end{array}$} & \multicolumn{2}{|c|}{$\begin{array}{l}\text { ComputationoftheSummar } \\
\text { Maturity Level }\end{array}$} \\
\hline $\begin{array}{l}\text { Maturity } \\
\text { Level(A) }\end{array}$ & $\begin{array}{c}\text { Sum of } \\
\text { statements } \\
\text { compliance } \\
\text { values (B) }\end{array}$ & $\begin{array}{c}\text { Number } \\
\text { of } \\
\text { maturity } \\
\text { level } \\
\text { statement } \\
s \text { (C) }\end{array}$ & $\begin{array}{l}\text { Maturitylevel } \\
\text { complience } \\
\text { value } D=A / C)\end{array}$ & $\begin{array}{l}\text { Not normalized } \\
\text { compliences } \\
\text { valuesE- }(\mathrm{B} / \mathrm{C})\end{array}$ & $\begin{array}{c}\text { Normalize } \\
\text { d } \\
\text { complience } \\
\text { s values } \\
\text { F=[E/Sum(E } \\
1]\end{array}$ & $\begin{array}{c}\text { Normalized } \\
\text { compliences } \\
\text { values } \\
\mathrm{G}=[\mathrm{E} / \mathrm{Sum}(\mathrm{E})]\end{array}$ & $\begin{array}{l}\text { Contributio } \\
{ }_{H}^{n}=\left(A^{*} G\right)\end{array}$ \\
\hline 0 & 0,99 & 3 & 0,33 & 0,33 & 0,116 & 0,116 & 0,00 \\
\hline 1 & 1,99 & 4 & 0,50 & 0,50 & 0,175 & 0,175 & 0,17 \\
\hline 2 & 2,65 & 5 & 0,53 & 0,53 & 0,186 & 0,186 & 0,37 \\
\hline 3 & 2,98 & 6 & 0,50 & 0,50 & 0,174 & 0,174 & 0,52 \\
\hline 4 & 2,98 & 6 & 0,50 & 0,50 & 0,174 & 0,174 & 0,70 \\
\hline \multirow[t]{2}{*}{5} & 3,97 & 8 & 0,50 & 0,50 & 0,174 & 0,174 & 0,87 \\
\hline & & & Total & 2,85 & 1,000 & $\begin{array}{l}\text { Total Maturity } \\
\text { Level }\end{array}$ & 2,64 \\
\hline
\end{tabular}

Kendali proses DS11 pembahasan tentang Pengelolaan Data. Dalam hal ini dibahas mengenai hal-hal yang terkait dengan pengelolaan data seperti manajemen data, tata kelola keamanan data, hingga penanggung jawab pengelolaan data tersebut.

Tabel 8 diatas menunjukkan nilai hasil yang di peroleh adalah 2,64 (Repeatable but intuitive). Hasil tersebut menggambarkan bahwa manajemen telah menyadari bahwa sangat dibutuhkan sebuah pengelolaan data yang sistematis. Hal tersebut didasari pada jumlah data yang semakin berkembang secara kuantitas sehingga dibutuhkan system back-up dan pengamanan data terpadu. Adapun Hasil Perhitungan DS12 Mengelola Fasilitas, untuk Maturity Level 0-5 dari Satu Responden yaitu :

Table 9 Hasil Perhitungan DS 12 Level 0-5 dari Satu Responden

\begin{tabular}{|c|c|c|c|c|c|c|c|}
\hline \multicolumn{4}{|c|}{$\begin{array}{l}\text { Computationofthematuritylevel } \\
\text { CompliencesValue }\end{array}$} & \multicolumn{2}{|c|}{$\begin{array}{l}\text { Computation of the normalized } \\
\text { Complience Veltor }\end{array}$} & \multicolumn{2}{|c|}{$\begin{array}{c}\text { ComputationoftheSummary } \\
\text { Maturity Level }\end{array}$} \\
\hline $\begin{array}{l}\text { Maturi } \\
\text { ty } \\
\text { Level } \\
\text { (A) }\end{array}$ & $\begin{array}{l}\text { i Sum of } \\
\text { statemen } \\
\text { ts } \\
\text { complianc } \\
\text { evalues } \\
\text { (B) }\end{array}$ & $\begin{array}{c}\text { Number } \\
\text { of } \\
\text { maturity } \\
\text { level } \\
\text { statement } \\
s(c)\end{array}$ & $\begin{array}{c}\text { Maturitylevel } \\
\text { complience } \\
\text { value } D=(B / C)\end{array}$ & $\begin{array}{l}\text { Not normalized } \\
\text { compliences } \\
\text { values } E=(B / C)\end{array}$ & $\begin{array}{c}\text { Normalized } \\
\text { compliences } \\
\text { values } \\
\mathrm{F}=[\mathrm{E} / \mathrm{Sum}[\mathrm{E} \mid \mathrm{E})\end{array}$ & $\begin{array}{c}\text { Normalized } \\
\text { compliences } \\
\text { values } \\
\text { G=[E/Sum(E)] }\end{array}$ & $\begin{array}{c}\text { Contributio } \\
n \\
H=\left(A^{*} G\right]\end{array}$ \\
\hline 0 & 0,99 & 2 & 0,50 & 0,50 & 0,157 & 0,157 & 0,00 \\
\hline 1 & 1,99 & 3 & 0,66 & 0,66 & 0,211 & 0,211 & 0,21 \\
\hline 2 & 2,65 & 4 & 0,66 & 0,66 & 0,211 & 0,211 & 0,42 \\
\hline 3 & 2,98 & 7 & 0,43 & 0,43 & 0,135 & 0,135 & 0,41 \\
\hline 4 & 3,97 & 8 & 0,50 & 0,50 & 0,158 & 0,158 & 0,63 \\
\hline \multirow[t]{2}{*}{5} & 3,64 & 9 & 0,40 & 0,40 & 0,129 & 0,129 & 0,64 \\
\hline & & & Total & 3,15 & 1,000 & $\begin{array}{l}\text { Total Maturity } \\
\text { Level }\end{array}$ & 2,31 \\
\hline
\end{tabular}

Kendali proses DS12 adalah pembahasan tentang pengelolaan fasilitas. Dalam hal ini fasilitas yang dimaksud adalah seluruh aset pendukung penerapan teknologi sistem informasi.

Tabel 9 diatas menunjukkan nilai hasil yang diperoleh adalah 2,31 (Repeatable but intuitive). Hasil yang menggambarkan bahwa manajemen belum memikirkan secara detil bahwa pemeliharaan seluruh fasilitas Sistem Informasi akan mempengaruhi kinerja secara keseluruhan. Saat ini pengelolaan fasilitas hanya mengandalkan pada praktek-praktek yang baik dari beberapa individu.

\section{HASIL PENGUKURAN TINGKAT KEMATANGAN}

Dari proses pengukuran yang telah dilakukan dan tampak diatas, didapatkan hasil tingkat pengukuran kematangan implementasi Sistem Informasi Perpustakaan SMK Tunas Harapan pada tingkat kematangan COBIT 4.1. Hasil tersebut tampak seperti pada tabel 10.

\section{Table 10 Hasil Pengukuran Tingkat Kematangan Untuk Keseluruhan} Responden

\begin{tabular}{cclcc}
\hline No & Kode & \multicolumn{1}{c}{ Proses } & $\begin{array}{c}\text { Hasil } \\
\text { Pengujian }\end{array}$ & $\begin{array}{c}\text { Tingkat } \\
\text { Kematangan }\end{array}$ \\
\hline 1 & DS1 & $\begin{array}{l}\text { MenetapkandanMengatur Tingkat } \\
\text { Layanan }\end{array}$ & 2,74 & Repeatable but Intuitive \\
\hline 2 & DS4 & Memastikan Ketersediaan Layanan & 2,70 & Repeatable but Intuitive \\
\hline 3 & DS5 & Memastikan Keamanan Sistem & 2,67 & Repeatable but Intuitive \\
\hline 4 & DS7 & Mendidik dan Melatih Pengguna & 2,65 & Repeatable but Intuitive \\
\hline 5 & DS8 & Mengelola Bantuan Layanan dan & 2,61 & Repeatable but Intuitive \\
\hline 6 & DS10 & Mengelola Masalah & 2,64 & Repeatable but Intuitive \\
\hline 7 & DS11 & Mengelola Data & 2,63 & Repeatable but Intuitive \\
\hline 8 & DS12 & Mengelola Fasilitas & 2,71 & Repeatable but Intuitive \\
\hline & \multicolumn{2}{c}{ Rata-rata keseluruhan } & 2,67 & Repeatable but Intuitive \\
\hline
\end{tabular}

\section{ANALISIS HASIL}

a. Menetapkan dan Mengatur Tingkat Layanan (DS1)

Kendali proses Penghantaran dan Dukungan 1 pembahasan tentang penetapan dan pengaturan tingkat layanan. Penetapan dan pengaturan tingkat layanan sangat dibutuhkan, sehingga setiap individu memiliki tanggung jawab sesuai dengan peranannya masing-masing.

Tabel 10 diatas menunjukkan nilai hasil yang diperoleh dari tingkat kematangan adalah 2,74 (Repeatable but Intuitive). Hasil tersebut menunjukkan bahwa SMK Tunas Harapan telah memiliki beberapa pendekatan secara intuitif untuk mengindetifikasikan telah tersedia. Setiap kegagalan layanan didefinisikan namun solusinya hanya bersifat informal. Namun 
demikian belum ada pengukuran kepuasan pelanggan secara rutin.

\section{b. Memastikan Ketersediaan Layanan (DS4) \\ Kendali proses Penghantaran dan} Dukungan 4 pembahasan tentang kepastian ketersediaan layanan. Perpustakaan SMK Tunas Harapan sebagai organisasi yang bergerak dalam bidang layanan, harus dapat memastikan layanan yang tersedia berjalan dengan baik sehingga kebutuhan pengguna terpenuhi.

Tabel 10 diatas menunjukkan nilai hasil yang dicapai dari tingkat kematangan adalah 2,70 (Repeatable but Intuitive). Hal tersebut menggambarkan bahwa praktek kesinambungan layanan merupakan hal yang wajib, namun kesuksesannya bergantung pada individu.

\section{c. Memastikan Keamanan Sistem (DS5)}

Kendali proses Penghantaran dan Dukungan 5 adalah pembahasan tentang memastikan keamanan sistem. Sistem Informasi Perpustakaan sebagai teknologi baru, dalam penerapannya tentu membutuhkan pengamanan. Oleh karena itu keamanan sistem harus dipastikan terlebih dahulu.

Tabel 10 diatas menunjukkan nilai hasil yang dicapai dari tingkat kematangan adalah 2,67 (Repeatable but intuitive). Hasil tersebut menggambarkan bahwa tanggung jawab dan akuntabilitas keamanan TI ditugaskan kepada pengelola keamanan $\mathrm{TI}$ dengan otoritas terbatas. Pelaporan tentang keamanan TI lengkap namun kurang sesuai. Keamanan $\mathrm{TI}$ hanya dilihat sebagai tanggung jawab domain dan bisnis TI dan tidak melihat keamanan $\mathrm{TI}$ sebagai bagiannya. Mengingat pentingnya keamanan TI maka tanggung jawab atas hal tersebut harus ditetapkan. Resiko dan analisis dampak keamanan TI secara konsisten dilakukan.

\section{d. Mendidik dan Melatih Pengguna (DS7)} Kendali proses Penghantaran dan Dukungan 7 adalah pembahasan tentang mendidik dan melatih pengguna. Pada proses ini dibahas mengenai bagaimana mencapai tujuan penerapan teknologi Sistem Informasi dengan cara membangun sumber daya manusia sebagai pengguna teknologi tersebut.

Tabel 10 diatas menunjukkan nilai hasil yang diperoleh dari tingkat kematangan adalah 2,65 (Repeatable but Intuitive). Hal tersebut menggambarkan bahwa kebutuhan akan adanya pelatihan mulai diidentifikasi dalam rencana kinerja individu karyawan akan tetapi belum memiliki proses pelatihan dan pendidikan yang standar dan didokumentasikan. Selain

itu tidak ada kontrol terhadap kepatuhan pelaksanaan dengan terus menerus meninjau dan memperbaharui program dan proses pendidikan dan pelatihan.

e. Mengelola Bantuan Layanan dan Insiden (DS8)

Kendali proses Penghantaran dan Dukungan 8 pembahasan tentang pengelolaan bantuan layanan dan insiden. Dalam hal ini dibahas tentang bagaimana pengelolaan bantuan layanan dan insiden terkait penerapan Sistem Informasi sebagai teknologi informasi.

Tabel 10 diatas menunjukkan nilai hasil yang diperoleh dari tingkat kematangan adalah 2,61 (Repeatable but intuitive). Hasil tersebut menggambarkan bahwa dalam memenuhi permintaan pengguna dan pengelolaan insiden belum menggunakan suatu standar system yang didukung oleh kualitas alat dan personilnya.

\section{f. Mengelola Masalah (DS10)}

Kendali proses Penghantaran dan Dukungan 10 pembahasan tentang pengelolaan masalah. Dalam hal ini di bahas bagaimana mengelola masalah yang muncul saat penerapan Sistem Informasi.

Tabel 10 diatas menunjukkan nilai hasil yang diperoleh dari tingkat kematangan adalah 2,64 (Repeatable but intuitive). Hasil tersebut menggambarkan bahwa pada setiap masalah yang muncul saat penerapan Sistem Informasi belum dapat terkelola dengan baik. Hal tersebut dikarenakan tidak adanya personil khusus yang mampu mengindentifikasi masalah dan memberikan solusi. Selain itu, belum dimilikinya suatu alur proses mulai dari pendataan masalah, identifikasi masalah, disposisi penanggung jawab penanganan masalah hingga solusi dari masalah tersebut.

\section{g. Mengelola Data (DS11)}

Kendali proses Penghantaran dan Dukungan 11 pembahasan tentang Pengelolaan Data. Dalam hal ini dibahas mengenai hal-hal yang terkait dengan pengelolaan data seperti manajemen data, 
tata kelola keamanan data, hingga penanggung jawab pengelolaan data tersebut.

Tabel 10 diatas menunjukkan nilai hasil yang di peroleh dari tingkat kematangan adalah 2,63 (Repeatable but intuitive). Hasil tersebut menggambarkan bahwa manajemen telah menyadari bahwa sangat dibutuhkan sebuah pengelolaan data yang sistematis. Hal tersebut didasari pada jumlah data yang semakin berkembang secara kuantitas sehingga dibutuhkan system back-up dan pengamanan data terpadu.

\section{h. Mengelola Fasilitas (DS12)}

Kendali proses Penghantaran dan Dukungan 12 adalah pembahasan tentang pengelolaan fasilitas. Dalam hal ini fasilitas yang dimaksud adalah seluruh aset pendukung penerapan teknologi sistem informasi.

Tabel 10 diatas menunjukkan nilai hasil yang diperoleh dari tingkat kematangan adalah 2,71 (Repeatable but intuitive). Hasil yang menggambarkan bahwa manajemen belum memikirkan secara detil bahwa pemeliharaan seluruh fasilitas Sistem Informasi akan mempengaruhi kinerja secara keseluruhan. Saat ini pengelolaan fasilitas hanya mengandalkan

pada praktek-praktek yang baik dari beberapa individu.

\section{REKOMENDASI}

1. Menetapkan dan Mengatur Tingkat Layanan, seharusnya SMK Tunas Harapan membuat kerangka kerja tingkat layanan manajemen antara pelanggan dan penyedia layanan, agar pelanggan dan penyedia layanan mengetahui rencana-rencana kerja yang akan dilakukan, sehingga perkerjaan tersebut lebih terarah.

2. Memastikan Ketersediaan Layanan, SMK Tunas Harapan sebaiknya menjamin pelayanan yang berkelanjutan dan menyeluruh, agar dapat mendukung pelayanan yang lebih baik lagi untuk kedepannya.

3. Memastikan Keamanan Sistem, SMK Tunas Harapan sudah menjamin keaman sistem maka perlu dipertahankan dan ditingkatkan lagi.

4. Mendidik dan Melatih Pengguna, SMK Tunas Harapan seharusnya mengadakan pendidikan dan latihan para pengguna untuk pengembangan sistem ke depannya, agar sistem yang digunakan dapat memenuhi kebutuhan dan sesuai dengan kemajuan teknologi saat itu.

5. Mengelola Bantuan Layanan dan Insiden, SMK Tunas Harapan sudah mengelola layanan dan pertanyaan pelanggan namun perlu dipertahankan dan ditingkatkan lagi.

6. Mengelola Data, SMK Tunas Harapan sudah mengelola data yang ada maka perlu dipertahankan dan ditingkatkan lagi.

7. Mengelola Fasilitas, seharusnya perusahaan melakukan perlindungan dengan menyediakan peralatan khusus untuk mengawasi dan mengendalikan lingkungan seperti dipasang kamera tersembuyi sebagai pengendalian terhadap kemungkinan ancamanancaman baik dari luar maupun dari dalam.

8. Dari Analisis Domain Deliver and Support (DS) yang diterapkan di SMK Tunas Harapan dilihat dari hasil kuesioner ratarata perhitungan maturity levelnya yaitu berada diposisi 2,67 (repeatable but intuitive). Maka hal yang harus diperhatikan adalah SMK Tunas Harapan adalah tidak memiliki prosedur untuk mengutamakan layanan pelanggan. Dari temuan yang telah didapat, maka rekomendasi untuk Domain Deliver and Support (DS) yaitu, sebaiknya berusaha untuk meningkatkan ke level 3 atau 4, dengan membuat prosedur dalam mengutamakan layanan pelanggan untuk lebih meningkatkan kualitas layanan ke depan.

\section{KESIMPULAN}

Penelitian mengenai Analisis Tingkat Kematangan Sistem Informasi Perpustakaan di SMK Tunas Harapan didapat beberapa kesimpulan :

1. Dari hasil penelitihan ini diperoleh tingkat kematangan Sistem Informasi Perpustakaan SMK Tunas Harapan berada pada level rata-rata 2,67 (repeatable but intuitive) dengan rincian adalah : DS1 Menetapkan dan Mengatur Tingkat Layanan 2,74 (repeatable but intuitive), DS4 Memastikan Ketersediaan Layanan 2,70 (repeatable but intuitive), DS5 Memastikan Keamanan Sistem 2,67 
(repeatable but intuitive), DS7 Mendidik dan Melatih Pengguna 2,65 (repeatable but intuitive), DS8 Mengelola Bantuan Layanan dan Insiden 2,61 (repeatable but intuitive), DS10Mengelola Masalah 2,64 (repeatable but intuitive), DS11 Mengelola Data 2,63 (repeatable but intuitive), DS12 Mengelola Fasilitas 2,71 (repeatable but intuitive).

2. Dari hasil penelitian tersebut menunjukkan kualitas Sistem Informasi Perpustakaan SMK Tunas Harapan sudah berada pada posisi level 2,67 (repeatable but intuitive) sehingga sudah mendekati tingkat kematangan 3 (Defined process).

\section{SARAN}

1. Sebaiknya dilakukan penelitihan lanjutan dengan menambah domain proses atau menyertakan semua domain proses yang ada pada COBIT untuk mengetahui posisi tingkat kematangan Sistem Informasi Perpustakaan SMK Tunas Harapan.

2. Sebaiknya manajemen dan pengelola perpustakaan SMK Tunas Harapan berusaha memperbaiki dan meningkatkan semua yang berkaitandengan layanan perpustakaan untuk bisa mencapai tingkat kematangan 4 (Managed and Measurable)

3. Sebaiknya SMK Tunas Harapan, memperhatikan fasilitas dan tanggung jawab perpustakaan guna menjamin akan keberlangsungan layanan yang lebih meningkat.

\section{REFERENSI}

[1]. A. Al-rasyid, "Analisis Audit Sistem Informasi Berbasis COBIT 5 Pada Domain Deliver, Service, and Support ( DSS ) ( Studi Kasus : SIM-BL di Unit CDC PT Telkom Pusat. Tbk )," eProceeding Eng., vol. 2, no. 2, pp. 6110-6123, 2015.

[2]. A. Amnah, "Analisa Proses Audit Sistem Informasi Biro Manajemen Asset Dan Logistik Menggunakan Framework Cobit 4.1. Pada Institut Informatika Dan Bisnis Darmajaya Bandar Lampung," J. Inform. Darmajaya, vol. 14, no. 1, pp. 72-83, 2014.
[3]. J. F. A. Fenny, "Audit Sistem Informasi Menggunakan Framework," Semin. Nas. Sains dan Teknol. 2017, no. November, pp. 1-11, 2017.

[4] C. Kesuma and D. N. Kholifah, "Sistem Informasi Akademik Berbasis Web Pada Lkp Rejeki Cilacap," EVOLUSI J. Sains dan Manaj., vol. 7, no. 1, p. 83, 2019. 